Journal of Engineering and Applied Sciences 14 (4): 1374-1387, 2019

ISSN: 1816-949X

(C) Medwell Journals, 2019

\title{
Strategic Market Selection for Exporting Weapon Systems: Korean Case
}

\author{
Jihyun Kim, Jaehyun Han and Sukjae Jeong \\ School of Business Administration, Kwangwoon University, 01897 Seoul, South Korea
}

\begin{abstract}
The primary objective of the traditional arms industry was to focus on strengthening domestic military strength. Accordingly, most of the relevant researches have focused on development and evaluation of core weapons technologies. Relying solely on domestic demands greatly limits the possibility of the arms industry's growth. Furthermore, global financial crisis and military budget cuts are compelling the companies to seek broader markets. However, significant distinction from general export as well as both the competitiveness and high entrance barrier of the global arms trade makes such endeavor demanding. Such adversity necessitates dissimilar studies that will focus on evaluating the feasibility of exporting weapon systems and identifying promising markets. This study presents a three-step analytical procedure that combines both quantitative and qualitative approaches to address this issue, selection of buying power indices and evaluation of competing weapons systems, two-phase screening for selecting promising countries using both quantitative and qualitative analyses and final selection of target countries by utilizing the Bruce Merrifield-Ohe (BMO) Method. The proposed research is evaluated by applying the proposed procedure to two actual weapon system export cases in Republic of Korea with opposite results a success and a failure.
\end{abstract}

Key words:Weapon system, export feasibility, market identification, market evaluation, promising market selection, $\mathrm{BMO}$

\section{INTRODUCTION}

In recent years, corporate sustainability issues have become strategically important to managerial decision makers in implementing business strategy that considers every dimension of how a business operates in the ethical, social, environmental, cultural and economic spheres. The economic sustainability in which we have interest can be viewed from three different perspectives; Market-industry, resource-based and institutional based (Lloret, 2016). The research indicated that the successful practices of sustainability using company's business strategy will ensure the competitive advantage in targeted market. Jin et al. (2017) emphasized that efficient coordination of business strategies covering multiple business aspects can improve the financial performance and value of a firm which are the evaluation indices regarded important from corporate economic sustainability point of view. Baumgartner (2014) noted that success and profitability of a company can lead to sustainable growth. To this end, companies necessitate a sustainable framework that will identify both opportunities and threats of entering emerging market. Within this framework, identification of promising new items which will ensure companies to sustain their business plays a key role (Jeong et al., 2016). In economic terms, implementing corporate sustainability strategies based on this framework will enable more sustainability and more success (Baumgartner, 2014). The defense industry is a capital-intensive industry that requires large scale facility investment and maintenance cost. In addition, unlike general products, initial development of weapon system have a significant characteristic difference. It usually follows the ETO (Engineer To Order) manufacturing method with extremely limited demand that is solely requested by the domestic military. Starting in such bilateral monopoly market, it is crucial to ensure economic scales by securing both domestic and foreign demand.

Therefore, it is imperative to augment foreign demands through export to ensure and increase competitiveness. However, the defense market is notorious for its high entry barrier and limited accessibility to the customer's weapon purchase information. And because the decision to purchase weaponty is usually made by the government with its own political agenda, it is vital for both the government and the industry to identify promising countries to export to and develop early response strategy to guarantee successful weapons trade. To secure competitiveness of domestic weapon system in target countries (export competitiveness) and to hold a lead, strategic, market oriented research analysis must be performed from the early planning stage and clear identification of the target market must be made from marketing point of view.

Corresponding Author: Sukjae Jeong, School of Business Administration, Kwangwoon University, 01897 Seoul, South Korea 
In Korea, multilateral analysis of economic feasibility, technology and military force improvement is being performed to construct strategies for efficient weapon system research and development. However, strategic approach to acquire export competitiveness through market analysis of market environment and potential customer's demands is lacking.

It is important for the defense industry and the government to develop and improve both related policies and systems and also to possess innovative weapons manufacturing technologies. But to vitalize exporting weapon systems, it is critical to take managerial view of the defense industry into consideration and to conduct marketing approach to analyzing weapon oriented market analysis. This study proposes a new decision process to screen and select promising markets for exporting the Korean weapon system. The validity and applicability of the proposed methodology are evaluated with the application to two cases of exporting T-50, a Korean advanced trainer jet.

The proposed evaluation model for strategic market selection enables early recognition of promising countries for exporting weapon systems. The Korean government is aiming to boost weapon systems export through "Selection and focus" and when developing customized export strategies, the evaluation model is expected to make a huge contribution.

There has been much research on identifying factors that have influence on weapon systems export. Although, it is apparent that the prices of similar and competing weapons system as well as possession of technological competitiveness are important, the existence of the market for the weapons system and the competition level of market must also be considered (Zolingen and Klaassen, 2003). In addition, marketing ability and $\mathrm{A} / \mathrm{S}$ capability of both the government and the weapons firm that wish to export are also important. Furthermore, when evaluating the possibility of exporting weapons to a potential market (country) the support capacity of the exporting country, diplomatic relationship between the two countries and compatibility of the weapons system are also important factors.

By Han and Won (2012), the attractiveness of a weapons system exporting market was discussed. In their research, the importance of the following six indices were emphasized when evaluating export marketability: market size, market growth rate, threat of competitors, threat of substitutes, promoting factors and hindering factors.

Korea Institute for Defense Analysis (KIDA) (Anonymous, 2007) conducted a macro environment analysis research to identify the regional characteristics of the weapons markets through dividing the global weapons market into several regions. From this research, it was noted that diplomatic relations with Korea, economic and military level, frequency of armed conflicts and level of defense science and technology must be considered when evaluating export of weapon systems. To vitalize the export, political assistance through construction of weapons export support organization, establishment of trans-national weapons export cooperation network and improvement of financial support system for weapons export were suggested.

Jang and Ahn proposed using the following 6 factors to identify 10 promising countries to export weapons to: size of GDP, relations with neighboring countries, civilian and military relationship with Korea, defense budget and compatibility with Korean weapons systems. To expand the scale of weapons export, establishing government policies to develop weapon systems with export in consideration, consolidate relationship between weapons export and official development assistance and strengthen analytic function of weapons export market for individual country/weapon system were proposed.

Security Management Institute (Anonymous, 2015) considered competitiveness of the weapons system, environment of the weapons market and government support as the deciding factors of weapons export. The competitiveness of the weapons system were subdivided into price, performance and quality competitiveness. The environment of weapons market was categorized as foreign market demand forecast, competitiveness in comparison to competing systems and stature of the exporting firm in the weapons market. Also, the government support was subdivided into capability of government support for weapons export and development level of foundation of export for the target market.

Previous researches were limited to finding weapons export related factors and emphasizing their importance. As previously mentioned in the introduction to successfully export weapon systems, not only do these factors need to be identified but the overall decision process that includes the identification of promising target market needs to be established as well. Therefore, a three-phased systematic analysis procedure that can be used to select buying power indices and analyze competing weapon systems, identify promising countries to export domestic weapon system through comparison with competing weapon systems and finally select target countries for export.

There are two key factors that differentiate the proposed research from the previous researches for selecting promising countries for weapons export. First, most existing studies have solely focused on the quantitative analysis. We differentiate the analysis by 
including both quantitative and qualitative indices. The second distinguishing factor is that our approach uses both multi-phased evaluations and overall decision making while previous researches generally conducted AHP (Merrifield, 1978; Saaty, 2003) to obtain relative importance using quantitative data.

Most of international market selection models attempted to formalize the decision process which was composed of three stages, namely, screening, identification and selection (Gorecka and Szalucka, 2013; Sakarya et al., 2007; Koch, 2001; Cavusgil, 1985). In the screening stage, firms use macro-level data such as market size and growth rate to eliminate countries that do not meet their goals (Kumar et al., 1994). During the identification stage, sector (or industry) level data are gathered and assessed to exclude non-feasible market. The final selection stage determines the market which best fits the company's objectives given available resources (Aulakh, 1997). In the final stage, firm-level data are utilized to analyze forecasted sales, costs and profitability among others.

In such process, Cavusgil et al. (2004) suggested two methods to evaluate and decide which markets are attractive. The first method was to group the similar countries based on the social, economic and political factors by using the secondary market data and clustering approach. The similarities helped decision makers to evaluate possible synergies (Cavusgil et al., 2004; Huszagh, 1986). To identify key factors for screening, cluster and factor analysis were conducted (Sethi and Curry, 1973; Sheth and Lutz, 1971; Samli, 1977. Scholars have criticized grouping approaches because it focuses on the country level data and neglects the characteristics of a specific product. It is possible to have a situation where macro level data are similar but completely different at a product level market and vice versa. This approach also failed to consider the accessibility and reliability of the secondary data which can vary from one country to another which makes it more difficult to compare them (Sakarya et al., 2007).

Secondly, market estimation methods were suggested to rank countries based on aggregate market potential and overall attractiveness. The following criteria such as market size, growth rate and level of competition were used for the estimation. Some models used regression analysis to forecast demand for specific products (Lindberg, 1982). Market estimation approaches also failed to include the characteristics of a specific product and did not consider dynamic market environment (Sakarya et al., 2007).

Based on the existing methods used in civilian industry, we propose the following model to identify the promising markets (or countries) while reflecting the characteristics (the price and technology competitiveness) of weapon system.

\section{MATERIALS AND METHODS}

Unlike most civilian exports, exporting a specific weapon system is limited to only a few number of countries. Because of the scarcity of candidate countries to export to for each weapon system, it is crucial to subdivide and identify the countries with high probabilities of successful export from the target market. Successfully subdividing the target market requires technology and performance comparison with competing weapon systems as well as deducing price competitiveness. And even though a country may be a possible market for export, composite consideration of other factors such as compatibility with Korean weapon system, government support, differential marketing strategies need to be considered. Therefore, in order to correctly identify target market (country) a new evaluation model that enables comprehensive analysis of buying power of export target country as well as technology, performance and price rank comparison is in dire need. In addition, it is critical to break from qualitative analysis that relies on experts tempting to assess every factor and to harmoniously combine both data-driven quantitative analysis and expert's knowledge and experience based qualitative analysis. To fulfill such demands, a new evaluation model for clearly identifying strategic target market for weapon systems export is proposed in this study.

The proposed methodology of strategic market selection for weapon systems export consists of 3 stages and 6 steps. The overall procedure is depicted in Fig. 1.

The three stages are as follows. First, countries with the possibility of new weapons purchase and countries that possess weapon systems that are due for replacement owing to deterioration are identified. Next, promising countries are distinguished based on individual buying power indices and the actual export possibility to respective countries. Third, judging from market attractiveness and export competitiveness of domestic weapon system in said countries, promising countries are categorized into strongly recommended, moderately recommended and partially recommended countries.

The 6 steps are as follows. Identification and selection of buying power indices, analysis of competing and similar weapons system, grouping potential countries for export, 1st screening to select viable countries from potential countries, 2nd screening to select promising countries from viable countries and finalizing target counties for export. 


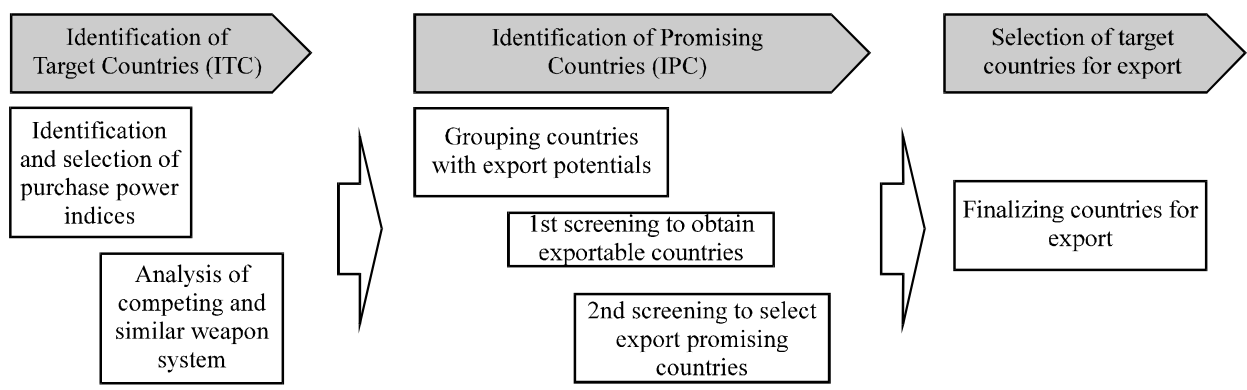

Fig. 1: Overall procedure of strategic market selection for weapon systems export

Buying power indices are selected from factors such as GDP, GDP per capita, economic growth rate, military expenditure, the size of military, the size of weapons export and import, military science and technology level, execution of MOU with Korea, possibility of military conflict and a database was constructed for 165 countries.

For the analysis of competing and similar weapon systems, the manufacturing country, model name, operating country, year of acquisition, expected year of deterioration based on life cycle and export price were investigated for weapon systems similar to Korean weapon systems. Based on the core technologies deduced from a survey of military/export experts, AHP analysis on the core technologies of Korean and similar weapons systems was performed. Using price performance ratio, competing weapon system were selected from similar weapon systems.

Out of 165 countries, countries with above average military conflict potential and military expenditure were Grouped (G1) as countries with the possibility of new purchase. And from countries that possess similar weapon systems, countries that possess weapon systems that are on the verge of deterioration and need to replace them soon were Grouped (G2) as countries that need replacement due to deterioration. From both group 1 and 2 , countries that are currently manufacturing and operating similar weapon systems were reasoned to believe that they would not purchase Korean weapon systems and therefore excluded. In addition, countries that are banned from export by the Ministry of Foreign Affairs were also excluded. In conclusion, all the remaining countries in both group 1 and 2 are 'potential countries for export'.

'Exportable countries' were selected from 'potential countries for export' ( $\mathrm{G} 1$ and G2) based on 5 main categories of buying power indices; Economic, military power, military science and technology, friendly relation with Korea and possibility of military conflicts. This step is labeled '1st screening'. During 1st screening, the 5 main buying power indices are converted to T-scores through normalization. Next, quartiles are established for all 5 indices. Countries with two or more indices that fall in lower quartile (or Q1) are removed from candidacy.

The remaining countries are called 'exportable countries'. 'Candidates of promising countries' are integrated results of overall scores of buying power indices and qualitative evaluation results of the experts. Quantitative overall scores are calculated from the countries that passed 1 st screening by multiplying the 5 buying power indices with relative weights of the indices obtained from AHP analysis. In addition, military export experts were surveyed on the qualitative factors to consider when exporting target weapon systems to respective countries using 10 point interval scale.

To normalize both the quantitative and qualitative scores they were transformed to Z-scores. Based on the $Z$-score transformation, countries that scored above average (which is 0) are chosen as 'candidates of promising countries'. This step is labeled 2nd screening.

The final stage is selecting 'target countries for export'. This is done by evaluating export possibilities of the 'candidates of promising countries'. Two evaluations criteria, market attractiveness and export competitiveness in comparison to competing weapon systems manufacturing countries are used to finalize the target country selection.

Detailed procedure; identification of target countries: Identification of target countries stage is shown in Fig. 2. First, experts are consulted to identify the factors that can be used to the buying power of each country for the weapon systems. Next, survey was conducted to obtain the level of impact each factor has on buying power. Based on the survey results, factors are grouped into 5 main categories and the data for 165 countries were collected. Next, AHP analysis was performed to obtain relative weights within the 5 main categories and relative weights within each sub categories (or indices). 


\begin{tabular}{|c|c|c|}
\hline Stages & Detailed steps & Detailed procedures \\
\hline \multirow{3}{*}{$\begin{array}{l}\text { Identification of } \\
\text { Target Countries } \\
\quad \text { (ITC) }\end{array}$} & $\begin{array}{l}\text { Identification and } \\
\text { selection of } \\
\text { purchase power } \\
\text { indices }\end{array}$ & $\begin{array}{l}\text { Delphi method ( } 1,2 \text {, rounds) for seeking purchasing indicators } \\
\text { Factor analysis for grouping among indicators } \\
\text { AHP method for promising among indicators } \\
\text { Database for purchasing power indicators buy } 165 \text { countries }\end{array}$ \\
\hline & \L & \\
\hline & $\begin{array}{l}\text { Analysis of } \\
\text { competing and } \\
\text { similar weapon } \\
\text { system }\end{array}$ & $\begin{array}{l}\text { Identification of competing and similar ones of target WS } \\
\text { Database for competing and similar WS (e.g., price, core tech. spec. etc.) } \\
\text { Expert survey for identifying core technology of WS } \\
\text { Price-performance ratio analysis between WS }\end{array}$ \\
\hline
\end{tabular}

Fig. 2: Identification of target countries stage

Database of weapon systems similar to Korean weapon systems was constructed and through expert consultation, core technologies were selected. Using AHP method, pairwise comparison was performed between Korean weapon system and similar weapon system. The results were used to evaluate the technology levels of each weapon systems. Lastly, price-performance ratio was used to finally select the competing weapon systems.

Buying power indices: Expert Delphi analysis (Dalkey, 1969) was performed to identify the buying power indices. In the first round of Delphi analysis, 15 experts from Defense Acquisition Program Administration (DAPA), Korea Institute for Defense Analysis (KIDA), Korea Institute for Industrial Economics and Trade (KIET), Korea Trade-Investment Promotion Agency (KOTRA) and Korea Defense Industry Trade Support Center (KODITS) were consulted to identify specific factors that can be used to evaluate the target countrie's buying power for Korean weapon export.

In the second round of Delphi analysis, 61 experts from KOTRA, DAPA, export managers in various defense industries and defense experts in related research centers were consulted to evaluate the level of impact the 29 indices from the first Delphi analysis have on weapon system buying power. The survey was performed using 7 point Likert scale. Of the 47 replies, 4 were excluded due to omitted response and the number of valid response was 43 .

All of the CV values were less than 0.5. Therefore, additional survey was not performed. To evaluate content validity, minimum CVR value of 0.4 was used (Choi et al., 2009). Military expenditure to defense power improvement budget ratio and acquisition plan to purchase new weapon systems had less than $0.4 \mathrm{CVR}$ values and hence removed from the final list. Table 1 shows the results of Delphi.

Correlation coefficient matrix was obtained for the buying power indices. And KMO and Bartlett's test of
Table 1: Results of Delphi

\begin{tabular}{|c|c|c|c|c|}
\hline Indices & Avg. & SD & $\mathrm{CV}$ & CVR \\
\hline GDP & 3.909 & 0.817 & 0.215 & 0.52 \\
\hline GDP per capita & 3.727 & 1.082 & 0.214 & 0.59 \\
\hline National growth rate & 3.545 & 0.844 & 0.268 & 0.71 \\
\hline Foreign aid & 2.978 & 0.729 & 0.290 & 0.84 \\
\hline Import over military budget & 2.910 & 0.931 & 0.268 & 0.42 \\
\hline Military R\&D size & 3.364 & 1.161 & 0.275 & 0.48 \\
\hline $\begin{array}{l}\text { Budget of new Weap on } \\
\text { System (WS) acquisition }\end{array}$ & 3.273 & 0.977 & 0.265 & 0.51 \\
\hline $\begin{array}{l}\text { Altemative payment } \\
\text { source other than cash }\end{array}$ & 3.091 & 1.064 & 0.264 & 0.72 \\
\hline Military expenditure & 2.955 & 0.684 & 0.241 & 0.64 \\
\hline $\begin{array}{l}\text { Increase rate of } \\
\text { military expenditure }\end{array}$ & 3.364 & 0.64 & 0.272 & 0.73 \\
\hline Military budget per capita & 3.173 & 0.933 & 0.286 & 0.55 \\
\hline Military budget over GDP & 3.264 & 0.931 & 0.249 & 0.45 \\
\hline Military force & 2.718 & 0.957 & 0.152 & 0.64 \\
\hline Scale of WS import & 3.355 & 0.957 & 0.179 & 0.45 \\
\hline Scale of WS export & 3.036 & 0.689 & 0.273 & 0.55 \\
\hline WS requirement & 3.764 & 0.969 & 0.244 & 0.56 \\
\hline WS possession & 4.091 & 1.205 & 0.249 & 0.82 \\
\hline Manufacturing capability of WS & 3.864 & 1.031 & 0.152 & 0.91 \\
\hline $\begin{array}{l}\text { National Science and } \\
\text { Technology level }\end{array}$ & 3.727 & 0.926 & 0.179 & 0.55 \\
\hline Diplomatic relation with Korea & 3.682 & 0.847 & 0.273 & 0.64 \\
\hline Purchase history of Korean WS & 3.591 & 0.963 & 0.244 & 0.55 \\
\hline $\begin{array}{l}\text { Military related MOU } \\
\text { agreement with Korea }\end{array}$ & 3.545 & 0.889 & 0.295 & 0.64 \\
\hline Government support & 3.455 & 1.091 & 0.250 & 0.55 \\
\hline $\begin{array}{l}\text { Military aid equipment } \\
\text { from Korea }\end{array}$ & 3.455 & 1.199 & 0.272 & 0.73 \\
\hline $\begin{array}{l}\text { Export and Import trade } \\
\text { in private sectors }\end{array}$ & 3.000 & 0.864 & 0.286 & 0.55 \\
\hline Territorial disputes & 3.318 & 1.024 & 0.160 & 0.43 \\
\hline $\begin{array}{l}\text { Possibility of military conflicts } \\
\text { with neighboring countries }\end{array}$ & 2.818 & 0.614 & 0.268 & 0.57 \\
\hline $\begin{array}{l}\text { Military enhancement budget } \\
\text { over military budget }\end{array}$ & 2.335 & 1.502 & 0.295 & 0.23 \\
\hline Plan for new WS acquisition & 2.135 & 0.950 & 0.250 & 0.18 \\
\hline
\end{tabular}

sphericity was performed to test the suitability of factor analysis. Using anti-image correlation and Measure of Sampling Adequacy (MSA), variable group was obtained from factor analysis.

Traditionally, factors with eigenvalues greater than 1 are chosen for analysis. However, the experts and previous research asserted that the possibility of military conflicts is one of the key factors that have influence on 
Table 2: Classification of indicators by factor analysis

\begin{tabular}{|c|c|c|c|c|c|c|c|}
\hline Index & Indicators & Factor 1 & Factor 2 & Factor 3 & Factor 4 & Factor 5 & Score \\
\hline "Economic" Index & GDP & 0.81185 & -0.11484 & 0.20528 & 0.09063 & 0.01254 & 0.27457 \\
\hline (International Monetary & GDP per capita & 0.79913 & 0.07773 & -0.17291 & 0.04998 & 0.12586 & 0.31129 \\
\hline Fund, 2014) & National growth rate & 0.74200 & 0.13387 & 0.39973 & 0.05841 & -0.12596 & 0.20496 \\
\hline \multirow[t]{7}{*}{ "Military power" index } & Military expenditure & -0.02557 & 0.67176 & 0.26273 & 0.01985 & 0.15564 & 0.34352 \\
\hline & Increase rate of military expenditure & 0.10814 & 0.65654 & 0.20950 & 0.07412 & 0.32556 & 0.32579 \\
\hline & Military budget per capita & 0.16837 & 0.62637 & 0.03844 & 0.34483 & 0.12588 & 0.28969 \\
\hline & Military budget over GDP & 0.32804 & 0.61713 & 0.10400 & -0.12303 & -0.05956 & 0.34204 \\
\hline & $\begin{array}{l}\text { Military force (The International the } \\
\text { International Institute of Strategic Studies, 2016) }\end{array}$ & -0.09614 & 0.58337 & 0.09745 & 0.48252 & -0.12336 & 0.2885 \\
\hline & Scale of WS import (Anonymous, 2016a, b) & 0.14465 & 0.6332 & -0.09512 & 0.23364 & 0.12333 & 0.31245 \\
\hline & Scale of WS export (Anonymous, 2016a, b) & 0.07478 & 0.6997 & -0.03698 & 0.32221 & 0.23865 & 0.47782 \\
\hline \multirow[t]{3}{*}{$\begin{array}{l}\text { "Military Science and } \\
\text { Technology" index }\end{array}$} & $\begin{array}{l}\text { Manufacturing capability of WS } \\
\text { (Anonymous, 2016a, b) }\end{array}$ & 0.08205 & 0.25110 & 0.69146 & 0.13025 & 0.14765 & 0.45628 \\
\hline & Military $R$ and $D$ size & 0.10070 & 0.51599 & 0.66172 & -0.05242 & 0.23698 & 0.16684 \\
\hline & National Science and Technology level & 0.12913 & 0.25063 & 0.68362 & 0.13051 & 0.36145 & 0.44368 \\
\hline "Friendly relation with & Diplomatic relation with Korea & 0.08205 & 0.25110 & 0.12336 & 0.69146 & 0.13025 & 0.45628 \\
\hline \multirow[t]{2}{*}{ Korea" index } & Purchase history of Korean WS & 0.00192 & 0.11363 & 0.05884 & 0.58325 & 0.14777 & 0.19948 \\
\hline & eement with Korea & 0.12913 & 0.25063 & -0.12563 & 0.68362 & 0.13051 & 0.44368 \\
\hline \multirow{2}{*}{$\begin{array}{l}\text { "Possibility of military } \\
\text { conflicts" index }\end{array}$} & Territorial disputes (Index, 2016) & 0.07706 & -0.06945 & 0.34028 & 0.08205 & 0.81451 & 0.65474 \\
\hline & $\begin{array}{l}\text { Possibility of military conflicts } \\
\text { with neighboring countries }\end{array}$ & 0.41058 & 0.32569 & -0.16169 & 0.00192 & 0.54616 & 0.39608 \\
\hline
\end{tabular}

Table 3: The results of AHP

\begin{tabular}{|c|c|c|c|c|}
\hline Index & Weight & Indicators & Weight & Rank \\
\hline \multirow{3}{*}{ "Economic" index } & 0.171 & GDP & 0.448 & 3 \\
\hline & & GDP per capita & 0.221 & 12 \\
\hline & & National growth rate & 0.331 & 7 \\
\hline \multirow[t]{7}{*}{ "Military power" index } & 0.265 & Military expenditure & 0.192 & 13 \\
\hline & & Increase rate of military expenditure & 0.128 & 16 \\
\hline & & Military budget per capita & 0.057 & 18 \\
\hline & & Military budget over GDP & 0.169 & 14 \\
\hline & & Military force & 0.141 & 15 \\
\hline & & Scale of WS import & 0.080 & 17 \\
\hline & & Scale of WS export & 0.233 & 10 \\
\hline \multirow[t]{3}{*}{ "Military Science and Technology" index } & 0.136 & Manufacturing capability of WS & 0.420 & 5 \\
\hline & & Military $R$ and $D$ size & 0.352 & 6 \\
\hline & & National Science and Technology level & 0.228 & 11 \\
\hline \multirow[t]{3}{*}{ "Friendly relation with Korea" index } & 0.227 & Diplomatic relation with Korea & 0.296 & 8 \\
\hline & & Purchase history of Korean WS & 0.440 & 4 \\
\hline & & Military related MOU agreement with Korea & 0.264 & 9 \\
\hline \multirow[t]{2}{*}{ "Possibility of Military conflicts" index } & 0.201 & Territorial disputes & 0.467 & 2 \\
\hline & & Possibility of military conflicts with neighboring countries & 0.533 & 1 \\
\hline Total & 1.000 & & 1.000 & \\
\hline
\end{tabular}

weapon system purchase. Therefore, it was concluded that in addition to the four factors chosen from PCA, "the possibility of military conflicts' was also included. Table 2 shows the classification of indicators by factor analysis.

The extracted factors are rotated to ease the analysis procedure. Of the many factor rotation methods, Varimax Method is used to simplify factors. The new factors with cumulative variance are listed in Table 2 . The first set of indicators are interpreted as 'GDP', 'GDP per capita' and 'National growth rate'. The second set of indicators are 'Military Expenditure', 'Increase Rate of military Expenditure', 'Military Budget per Capita', 'Military Budget over GDP', 'Military force', 'Scale of weapon system import' and 'Scale of weapon system export' and the third set of indicators are 'Manufacturing capability of WS', 'Military R\&D size' and 'National science and technology level'. The fourth set of indicators are translated as 'Diplomatic relation with Korea', Purchase history of Korean WS' and 'Military related MOU agreement with Korea' and the final fifth set of indicators are translated as 'Territorial disputes' and 'Possibility of military conflict with neighboring countries'.

AHP analysis was performed to obtain relative weights within the 5 main categories and relative weights within each sub categories (or indices). 20 weapon systems export experts from DAPA, Defense Agency for Technology and Quality (DTaQ) and defense industries were surveyed. The weights for each indices and the source of data are shown in Table 3 .

The total weight of evaluation items is 1.0000 with relative weights of each Indices are as follows. 'Economic index' with 0.171 , 'Military power index' with 0.265 , 'Military science and technology index' with 0.136 , 
'Friendly relation with Korea index' with 0.227 and 'Possibility of military conflict index' with 0.201 . Detailed look at the indicators revealed that 'Possibility of military conflict with neighboring countries' indicator had the highest weight of 0.533 and 'Military budget per capita' indicator had the lowest weight of 0.057 .

Among the 5 indices, 'Military power' index had the highest weight. This can be construed as the level of military power and the size of military expenditure of each country has very important impact on the weapon system buying power. The analysis results shown above are utilized later when calculating overall buying power during screening of countries with possibility of weapon system export.

Analysis of competing and similar weapon systems: When entering target market for weapon export, it is very important to ascertain the competitiveness of competing and substitute weapon system. If there are many competing weapon system in the global market, it indicates that the competition is fierce and that it is that much more difficult to export weapon systems to foreign countries. Another factor that needs to be considered is that when the life cycle of an existing weapon system is nearing its end, it opens the possibility of export to that country. Therefore, when considering weapon systems export, it is very important to identify the competing and substitute weapon systems, countries that are currently manufacturing the competing and substitute weapons and countries that are currently using the weapon system.

The detailed procedure of analyzing competing and similar weapon systems are as follows. In the first step, a database is constructed for weapon systems that are similar to Korean weapon systems. Based on the required type and level performance of Korean weapon systems, weapon systems with identical or similar platform are investigated and the manufacturing country, model name, operating country, year of acquisition, expected year of deterioration based on life cycle and export price for each weapon systems are databased. Detained information regarding weapon systems were obtained from Jane's DSF, Forecast International and several documents obtained on-line.

In the second step, the data for both Korean weapon systems and similar weapon systems are provided to a team of experts and they were asked to freely identify core technologies that can be used to evaluate technology competitiveness of relevant weapon systems. The team consisted of eleven experts working in defense industries and Defense Agency for Technology and Quality (DTaQ) and they were consulted via e-mail and telephone interviews. Based on the response frequency, three core technologies were identified.
In the third step of the procedure, relative importance among the core technologies as well as pairwise comparison of the identified core technologies between Korean weapon system and similar weapon system was performed through AHP analysis. Expert's responses with consistency $<0.2$ were excluded from the analysis. For each type of weapon systems, overall technology scores were obtained by using both individual technology points and relative importance among technologies.

In the fourth step, a matrix of price versus technology graph is constructed by utilizing the export price of similar weapon systems previously identified from weapon system database and the relative importance of technologies.

In the last step, weapon systems in competition with Korean weapon system in the export market are finally selected through price versus technology comparison.

Detailed procedure: identification of promising countries: Identification of promising countries stage is composed of three steps. First, countries with the possibility of new purchase and countries that need replacement due to deterioration are identified as potential countries for export. In the second, exportable countries are selected through 1 st screening. In the third step, candidates of promising countries are identified using 2 nd screening. Figure 3 shows the detail procedure of stage 2 .

Grouping potential countries for export: Countries with the possibility of new purchase are chosen from countries that currently do not possess competing and substitute weapon systems and have both high possibility of military conflict and high military expenditure. Countries that need replacement due to deterioration are chosen from countries that currently possess competing or similar weapon systems that are nearing their end of life cycle due to deterioration. From the two groups of countries, the countries that manufacture competing or similar weapon systems or countries that are banned from export are excluded.

1st screening to obtain exportable countries: In the 1 st screening, the 5 main buying power indices are converted to T-scores. This is done to enable elaborate comparison of relative level of buying power indices of each countries. The T-scores are converted values of original data to values with score distribution of mean 50 and standard deviation 10. As for calculating the values of buying power indices, relative importance obtained from previous AHP analysis are used. Because the countries with higher buying power indices have higher probability 


\begin{tabular}{|c|c|c|}
\hline Stages & Detailed steps & Detailed procedures \\
\hline \multirow{3}{*}{$\begin{array}{l}\text { Identification of } \\
\text { Promising } \\
\text { Countries (IPC) }\end{array}$} & $\begin{array}{l}\text { Grouping countries } \\
\text { with export } \\
\text { potentials }\end{array}$ & $\begin{array}{l}\text { G1: Countries with possibility of new purchase (disputes and military ) expenditure } \\
\text { G2: Countries that need replacement due to deterioration } \\
\text { Exclusion from group: WS manufacturing countries, export-banned countries }\end{array}$ \\
\hline & $\begin{array}{l}\text { 1st screening to } \\
\text { obtain exportable } \\
\text { countries }\end{array}$ & $\begin{array}{l}\text { T-score calculation for normalizing detailed items by five index } \\
\text { Quartiles of five index by export potential countries } \\
\text { Screening-out rule: countries having two more indicators located in Q1 }\end{array}$ \\
\hline & $\begin{array}{l}\text { 2nd screening to } \\
\text { select export } \\
\text { promising countries }\end{array}$ & $\begin{array}{l}\text { Calculation of quantitative score (weight sum of indicators) } \\
\text { Experts survey for identifying qualitative factors and assigning their scores } \\
\text { Z-transformation scores of quantitative and qualitative scores } \\
\text { Selection rule of candidates: countries in first quadrant in matrix graph }\end{array}$ \\
\hline
\end{tabular}

Fig. 3: Identification of target countries stage

Table 4: Qualitative evaluation criteria and necessity

Qualitative evaluation criteria Necessity

Topography/climate characteristics Even if the weapon system is operating domestically, the topography/climate characteristics of export target country may require modification (e.g. when exporting to Middle East, additional consideration for sand, dust, temperature must be made)

Weapon system compatibility Weapon system in consideration for export must possess compatibility with the weapon system currently operating in target country

Military aid equipment reception Countries with history of receiving military aid equipment from Korea tends to import more weap on systems Human network Lower the maturity of acquisition system is more important the relationship with circle of people that influence political decisions becomes

Government support capability Active support from the Blue House (the president), Ministry of National Defense (the minister), Ministry of Foreign Affairs (the minister, local ambassador), Ministry of Trade, Industry and Energy and Defense acquisition program administration can increase export possibility Because the end-user is the military, the defense companies are important but government support is also very important

Relationship with country in possession of source technology Relationship with the neighboring countries

When any source technology belongs to a foreign country, the relationship between the target export country and the country that possesses source technology may have influence on export possibility

Relationship with the neighboring countries of target export country must be considered. (e.g. while reviewing weap on sy stem export to a Middle Eastern country, friendly relations with Turkey hindered its success)

Offset Weapon system export is typically processed through offset, thus, if the possibility of offset is high, it leads to higher possibility of export

of weapons export, countries with two or more indices that lie in the lower quartile are removed from candidacy.

\section{2nd screening to select promising countries for export:} From the groups of potential countries for export, candidates of promising countries are chosen through 2nd screening. The selection procedure is as follows. The 2nd screening is processed using the quantitative scores obtained from the quantitative scores of individual countries and qualitative scores gathered from the survey of experts. First, the quantitative scores of target countries are calculated as follows. The overall score of purchase indices are obtained by multiplying the scores of 5 main buying power indices (economic, military power, military science and technology, friendly relation with Korea and possibility of military conflicts) with the relative weights of each index. This is defined as the overall quantitative score.
Next, the qualitative scores are calculated as follows. First, the qualitative factors when evaluating the possibility of export are extracted from the survey of experts. The factors that were identified from expert's opinions, although very difficult to quantify must be considered as shown in Table 4.

Potential countries for export were introduced to the experts and they were asked to assign points from 5 point interval scale on 8 factors. Based on the survey, overall qualitative evaluation scores were obtained for all countries with expert potentials.

To normalize the quantitative and qualitative scores for each country, they were transformed to Z-scores. The transformed scores depict the level of distance (in standard deviation unit) from mean.

The matrix graph with the $\mathrm{X}$-axis denoting the overall $\mathrm{Z}$-transformed quantitative scores and the $\mathrm{Y}$-axis denoting the overall Z-transformed qualitative scores is shown. The countries in the 1st quadrant, the countries with both positive $\mathrm{X}$ and $\mathrm{Y}$ values are chosen as candidates of promising countries. 


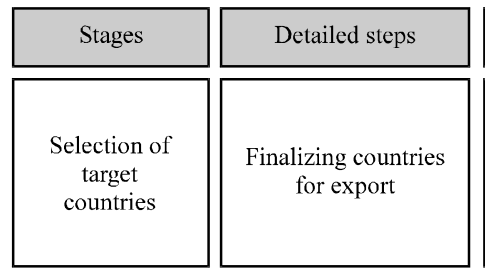

\begin{tabular}{|l|}
\hline \multicolumn{1}{|c|}{ Detailed procedures } \\
\hline BMO analysis with experts survey \\
Market attractiveness for export \\
Korean export competitiveness over competing countries \\
Selection of target countries: high BMO score \\
Classification of target countries: promising, conditionally promising \\
and inferior promising \\
\hline
\end{tabular}

Fig. 4: Selection of target countries

Table 5: Market attractiveness evaluation criteria and necessity

Market attractiveness evaluation criteria Necessity

Possibility of requirement institution $\quad$ To export a weapon system, the target country must display actions in advance that clearly displays the requirement for that specific weapon system

Evaluate the target country's possibility of instituting requirement within the next 10 years

Ease of market entry

Export possibility increases as the market entry barrier lowers

Possibility of sales profit

Scores are obtained by overall evaluation of previous successful export cases and recognition level of Korea

Existence of requirement for weap on system is undoubtedly important but the size of the requirement must be sufficient to ensure satisfactory sales profit

Evaluate sales profit based on the target country's probable requirement size

Sovereign credit rating

Export possibilities are high for countries with low risk of sovereign credit rating drop

Scores are assigned based on current and future sovereign credit rating of the target country

When any source technology belongs to a foreign country, the relationship between the target export

Relationship with country in

possession of source technology

country and the country that possesses source technology may have influence on export possibility Scores are assigned based on the relationship between the two countries

Table 6: Export competitiveness evaluation criteria and their necessity

$\begin{array}{ll}\text { Export competitiveness evaluation criteria } & \text { Necessity } \\ \text { Strategic cooperative relationship } & \begin{array}{l}\text { Evaluate comparative advantage in the area of strategic cooperative relationship such as technology transfer, } \\ \text { joint cooperative production, local production, modular export }\end{array} \\ \text { Marketing ability } & \begin{array}{l}\text { Evaluate comparative advantage in information acquisition about the target country and marketing } \\ \text { ability of the Korean weapon sy stem manufacturing company in that specific country }\end{array} \\ & \begin{array}{l}\text { Evaluate comparative advantage in governmental support of weapon system export } \\ \text { Government support }\end{array} \\ & \begin{array}{l}\text { Active support from The Blue House, Ministry of National Defense, Ministry of Foreign Affairs, Ministry } \\ \text { of Strategy and Finance (the export-import bank of Korea), Defense acquisition program administration }\end{array} \\ & \text { Evaluate comparative advantage in compatibility with the weapon system operating in target export country } \\ \text { Weapon system compatibility } & \text { Evaluate comparative advantage in relationship with influential people in political decisions } \\ \text { Human network } & \text { Lower the maturity of acquisition system is more important the relationship with circle of people that } \\ & \text { influence political decisions becomes } \\ & \text { Evaluate comparative advantage in cost-effectiveness }\end{array}$

Detailed procedure; selection of target countries for

export: As shown in Fig. 4, to select target countries for export from the candidates of promising countries, Bruce Merrifield-Ohe method (BMO) is used. Traditionally, $\mathrm{BMO}$ method is used to evaluate the validity of a new business field in a firm by classifying a new business as promising when the business attractiveness score is above 35 and business feasibility (business attractiveness+business fitness) score is above 80 .

Modifications are made to the BMO method for our paper. First, market attractiveness is evaluated for each candidate countries through expert survey as shows in Table 5. Next, export competitiveness as shows in Table 6 with respect to countries that manufacture competing weapon systems are obtained. Using these two criteria, target countries for export are finally chosen. The 15 experts underwent focus group interviews to obtain the factor to consider when evaluating market attractiveness and export competitiveness. Using the extracted evaluation criteria for market attractiveness and export competitiveness, 15 experts were provided with the information regarding competing weapon systems and they were asked to score each candidate countrie's evaluation criteria using 10 point interval scale. The scores were totaled and the overall market attractiveness and export competitiveness was calculated for all candidate countries.

Once all the scores were obtained, the countries with the total sum of market attractiveness and export competitiveness over 60 were labeled 'strongly recommended' countries, countries with total sum between 50 and 60 were labeled 'moderately recommended' and the countries with total sum of 50 or less were labeled 'partially recommended' countries. 


\section{RESULTS AND DISCUSSION}

Stepwise application of proposed methodology: T-50 advanced jet trainer is a weapon system developed in Korea for advanced training of Korean air force jet pilots. Initial production period was between December of 2003 and March of 2008. Follow-up production was between September of 2006 and December of 2012. T-50 is an advanced jet trainer with super-sonic flight capability and T-50 (advanced jet trainer), T-50B (Aerial Acrobatics), TA-50 (basic tactical trainer), FA-50 (light attacker) were developed and manufactured. Using formation standards, $\mathrm{T}-50$ can operate in an advanced training flight squadron.

Based on Jane's DSF data, weapon systems manufactured as advanced jet trainer were investigated and M-346, Hawk, Yak-130, L-159 and FTC-2000 were chosen as similar weapon systems. Table 7 shows the information regarding the competing weapon systems.

To extract the core technologies of an advanced jet trainer, experts were provided with a database containing information regarding $\mathrm{T}-50$ and the 5 similar weapon systems. 11 experts from weapon industry and $\mathrm{DTaQ}$ were surveyed through e-mail and phone interviews and they were asked to freely describe the core technologies to evaluate the technology level of advanced jet trainer. Based on the response three core technologies were obtained and they were mobility, convenience/safety and accessibility. Mobility is the maximum speed and maximum rate of climb, convenience/safety is the internal cockpit design with respect to operational convenience and safety and the accessibility is the possibility of flight just after completion of flight training. These three factors are also the key factors of technology competitiveness.

The experts were again surveyed to evaluate the relative importance of the three identified factors and rate the relative superiority of $\mathrm{T}-50$ in comparis on to 5 similar weapon systems. Market price of T-50 and competing weapon systems were obtained from weapon systems data base. Overall technology scores of each weapon systems were obtained from the AHP analysis of previous survey. It can be seen that the price of T-50 alone is far higher than its competitors. However, the overall technology score is far superior. As shows in Table 8, price-performance ratio of T-50 is still superior compared to competing weapon systems. But the difference is not too significant and therefore, all 5 weapon systems were selected as competing weapon systems.

Potential countries for export of T-50 weapon system is shown in Table 9. The number of countries with possible new purchase (G1) is 11 and the number of countries that need replacement due to deterioration (G2) is 28 . Therefore, the total number of potential countries for export is 29 .

The exportable countries that are obtained after the 1 st screening step is shown in Table 10. For all exportable countries, T-scores are calculated for 18 sub buying

Table 7: Similar and competing weapon systems

\begin{tabular}{|c|c|c|c|c|c|c|c|c|c|c|}
\hline \multirow[b]{2}{*}{ WS name } & \multirow[b]{2}{*}{$\begin{array}{l}\text { Manufacturing } \\
\text { country }\end{array}$} & \multirow[b]{2}{*}{$\begin{array}{l}\text { Company } \\
\text { name }\end{array}$} & \multicolumn{8}{|c|}{ Main performance } \\
\hline & & & $\begin{array}{l}\text { Empty weight } \\
(\mathrm{kg})\end{array}$ & $\begin{array}{l}\text { Max. takeoff } \\
\text { weight }(\mathrm{kg})\end{array}$ & $\begin{array}{l}\text { Max. speed } \\
(\mathrm{km} / \mathrm{h})\end{array}$ & $\begin{array}{l}\text { Max. g } \\
\text { limit (G) }\end{array}$ & $\begin{array}{l}\text { Min. g } \\
\text { limit }(G)\end{array}$ & $\begin{array}{l}\text { Rate of } \\
\text { climb (ft/min) }\end{array}$ & $\begin{array}{l}\text { Market } \\
\text { price }(\$ 10 \mathrm{~K})\end{array}$ & $\begin{array}{l}\text { Time of force } \\
\text { integration }\end{array}$ \\
\hline M-346 & Italy & $\begin{array}{l}\text { Alenia } \\
\text { Aermacchi }\end{array}$ & 4.900 & 7.100 & 1.093 & 8 & -3 & 21.000 & 2.200 & $2011 \sim$ \\
\hline Hawk & UK & $\mathrm{BAE}$ & 4.400 & 9.100 & 1.000 & 8 & -4 & 11.800 & 2.062 & $1992 \sim$ \\
\hline Yak-130 & Russia & Yakovlev & 5.390 & 7.250 & 1.059 & 8 & -3 & 9.840 & 1.870 & $2010 \sim$ \\
\hline L-159 & Czech & $\begin{array}{l}\text { Aero } \\
\text { Vodochody }\end{array}$ & 4.350 & 8.000 & 0.935 & 8 & -4 & 12.220 & 1.389 & $1999 \sim$ \\
\hline FTC-2000 & China & GAI & - & 9.800 & 1.100 & 8 & -3 & 31.496 & - & $2013 \sim$ \\
\hline
\end{tabular}

Table 8: Comparison among T-50 and competing weapon systems

$\begin{array}{llllll}\text { Weapon system } & \text { Mobility }(0.455) & \text { Convenience/safety }(0.091) & \text { Accessibility }(0.454) & \text { Total tech. score } & \text { Market price \$US Price-performance ratio }\end{array}$

M-346

$0.58 \quad 0.35$

0.35

$\begin{array}{ll}0.10 & 0.28 \\ 0.10 & 0.16\end{array}$

Hawk

Yak-130

$\begin{array}{ll}0.10 & 0.07\end{array}$

L-159

$0.04 \quad 0.07$

FTC-2000

0.10

0.07

0.45
0.22
0.08
0.08
0.08
0.08

0.50
0.17
0.10
0.09
0.06

3.500

3.500

1.800

2.538

1.900

1.389

1.620

0.16

0.15

0.08

0.09

0.09

Table 9: Potential countries for export

Country

Iraq, Egypt, Ukraine, Mexico, Philippines, Thailand, South Africa, Venezuela, Peru, Algeria, Colombia

Finland, Qatar, Vietnam, Oman, Saudi Arabia, Poland, Singapore, UAE, Sweden, Austria, Belgium, Brazil, USA, 
Table 10: The five buying power indices for exportable countries

\begin{tabular}{lccccc}
\hline Country & Economic index & $\begin{array}{l}\text { Military power } \\
\text { index }\end{array}$ & $\begin{array}{l}\text { Military Sci. and Tech. } \\
\text { index }\end{array}$ & $\begin{array}{c}\text { Friendly relation with } \\
\text { Korea }\end{array}$ & $\begin{array}{l}\text { Possibility of military } \\
\text { conflicts index }\end{array}$ \\
\hline Brazil & 37.62 & 39.99 & 32.49 & 51.99 & 27.09 \\
Chile & 33.38 & 39.77 & 34.01 & 51.42 & 22.94 \\
Colombia & 32.77 & 41.55 & 35.03 & 54.77 & 28.19 \\
Egypt & 32.48 & 41.12 & 35.54 & 51.38 & 31.38 \\
Greece & 34.12 & 41.06 & 32.74 & 54.96 & 26.91 \\
India & 37.87 & 56.83 & 30.92 & 56.47 & 31.38 \\
Indonesia & 33.65 & 45.55 & 34.90 & 58.35 & 27.52 \\
Iraq & 32.47 & 43.06 & 35.54 & 53.45 & 38.32 \\
Oman & 32.46 & 51.43 & 35.54 & 51.05 & 25.50 \\
Philippines & 32.47 & 39.66 & 35.28 & 60.99 & 30.39 \\
Saudi Arabia & 34.99 & 60.86 & 35.54 & 49.54 & 26.49 \\
Turkey & 34.07 & 48.29 & 32.05 & 57.60 & 29.92 \\
UAE & 36.62 & 49.11 & 33.76 & 55.15 & 25.15 \\
USA & 80.57 & 71.40 & 24.04 & 60.99 & 22.64 \\
First quartile (cutoff point) & 32.36 & 39.66 & 30.79 & 49.44 & 2.49 \\
\hline
\end{tabular}

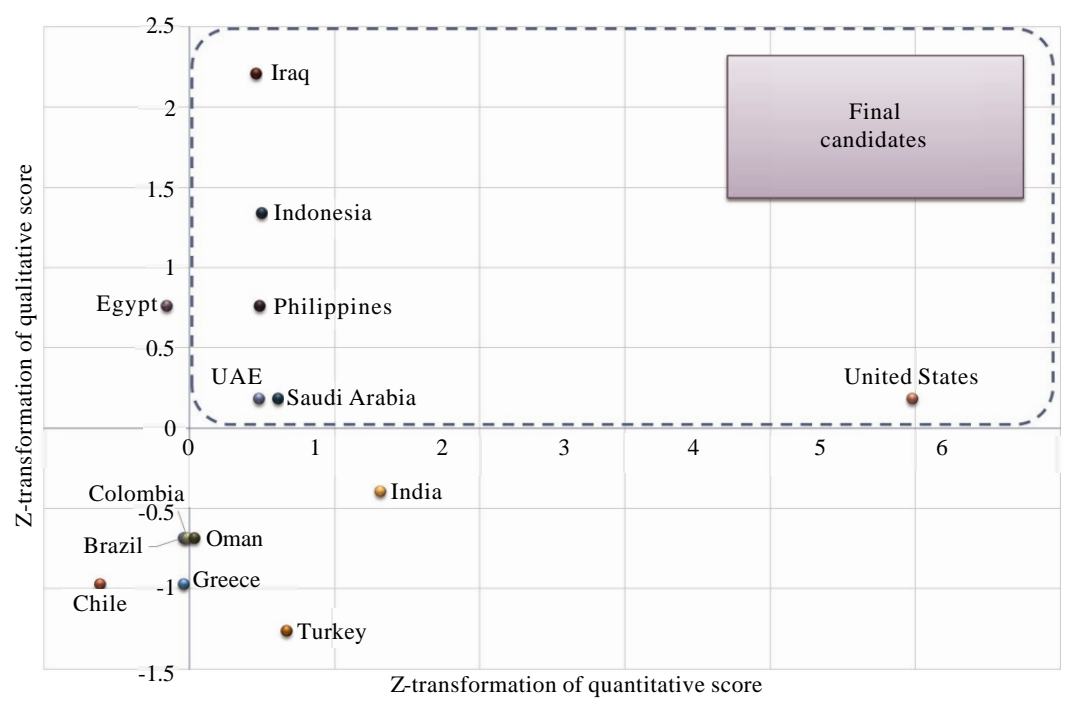

Fig. 5: The matrix graph

power indices and the scores of 5 main buying power indices are calculated by using the relative weights of sub indices. Based on the 5 main purchase indices, countries in the lower quartile are identified. It can be seen from Table 8 that cutoff points for each index are economic index with 32.36 points, military power index with 39.66 , military science and technology index with 30.79 , friendly relation with Korea with 49.44 and possibility of military conflicts with 22.49 points. Countries with scores less than the cutoff points are located in the lower quartile for each index. For each index, the countries in the lower quartile are shadowed in the table. Of the 5 buying power indices, the countries with two or more indices in the lower quartile are removed in the 1 st screening.

The selection of candidates of promising countries based on the overall quantified scores and the overall qualified scores from expert surveyis shows in Fig. 5. Matrix graph is used for the final selection of target countries for export. The $\mathrm{X}$-axis represents the overall $\mathrm{Z}$-transformed quantitative scores and the $\mathrm{Y}$-axis represents the overall $Z$-transformed qualitative scores. The countries in the 1st quadrant, the countries with both positive $\mathrm{X}$ and $\mathrm{Y}$ values are chosen as the final candidates of promising countries. The 6 final candidate countries are Indonesia, Iraq, Philippines, UAE and USA.

To select the target market, experts were asked to answer evaluation criteria for market attractiveness and export competitiveness. Table 11 and 12 show evaluation scores for Market Attractiveness (MA) and Export Competitiveness (EC), respectively.

Table 13 show the BMO results that the final target market countries were identified. Indonesia, Philippines and USA were labeled 'strongly recommended', UAE and Saudi Arabia were labeled 'moderately recommended' and Iraq was labeled 'partially recommended'. 
J. Eng. Applied Sci., 14 (4): 1374-1387, 2019

Table 11: Market attractiveness of six countries

\begin{tabular}{|c|c|c|c|c|c|c|}
\hline$\underline{\text { Market attractiveness }}$ & Indonesia & Iraq & Philippines & $\mathrm{UAE}$ & Saudi Arabia & USA \\
\hline WS demand of targeting country & 8 & 6 & 6 & 7 & 6 & 8 \\
\hline Accessibility of market entry into targeting country & 8 & 4 & 8 & 5 & 4 & 6 \\
\hline Expected amount of WS of targeting country & 4 & 5 & 4 & 5 & 5 & 6 \\
\hline Credit risk of targeting country & 5 & 4 & 4 & 5 & 5 & 8 \\
\hline Relation with targeting country and original tech. possession country & 7 & 5 & 8 & 6 & 6 & 8 \\
\hline Total & 32 & 24 & 30 & 28 & 26 & 36 \\
\hline
\end{tabular}

Table 12: Export competitiveness of six countries

\begin{tabular}{lllllll}
\hline Export competitiveness & Indonesia & Iraq & Philippines & UAE & Saudi Arabia & USA \\
\hline Strategic collaboration & 8 & 5 & 9 & 5 & 6 & 8 \\
Marketing ability & 9 & 6 & 8 & 6 & 5 & 7 \\
Government support & 9 & 6 & 9 & 7 & 6 & 6 \\
WS compatibility & 7 & 5 & 9 & 6 & 7 & 8 \\
Human network & 9 & 5 & 9 & 6 & 6 & 7 \\
Price competitiveness & 6 & 4 & 6 & 4 & 7 & 7 \\
Offset (industrial cooperation) & 9 & 4 & 8 & 42 & 45 & \\
Total & 57 & 35 & 41.43 & & & 32.14 \\
Conversion to 50 pt. & 40.71 & 25.00 & & & & 35.00 \\
\hline
\end{tabular}

Table 13: BMO results

\begin{tabular}{|c|c|c|}
\hline Target countries & Criteria of BMO & Countries \\
\hline Strongly recommended & $\mathrm{MA}+\mathrm{EC} \geq 60$ & $\begin{array}{l}\text { Indonesia, United States, } \\
\text { Philippines }\end{array}$ \\
\hline Moderately recomm & $\mathrm{MA}+\mathrm{EC} \geq 50$ & UAE, Saudi Arabia \\
\hline Partially recommended & Others & Iraq \\
\hline
\end{tabular}

Comparison to actual T-50 export case: UAE and Indonesia was both considered for exporting T-50 weapon system. In the UAE case, the competing weapon system was M-345 manufactured in Italy. UAE possessed sufficient military budget and T-50 was superior in terms of technology in comparison to M-346. And from weapon system compatibility's point of view, another key factor to consider for weapon export, T-50 had better compatibility to jet fighters that UAE possessed. However, the price of T-50 was higher thus lowering competitiveness.

Eventually, although, T-50 possessed higher performance, higher price and inferior industrial cooperation (which UAE demanded) led to a failed attempt. It was later discerned that the friendly relationship between Italy and UAE greatly raised the export barrier.

On the other hand, export to Indonesia was a success even though the military budget was less than UAE's and quantitative competitiveness was much higher (YAK-130 from Russia, L-159 from Czechoslovakia, FTC-2000 from China). The price of T-50 was high in comparison to competing weapon systems and therefore, the competitiveness was low. However, price inferiority was overcome with financial support and with the high evaluation of previously exported basic trainer (KT-1) by the Indonesian Air Force led to a successful weapon export.

To validate the proposed target market selection model, the previous example was applied to the methodology. UAE was first grouped into G2 as a country that need replacement due to deterioration. In comparison to the competing weapon system, M-346, the price was higher but the performance was superior. The cost-effectiveness was slightly superior and it was concluded that competitiveness was high. In the 1st screening, UAE was in the top group for economic, military power and friendly relation indices. For military science and technology and possibility of military conflicts indices, UAE was in the middle group and therefore, UAE was included in the exportable countries. In the 2 nd screening, $\mathrm{UAE}$ received above average points in both overall quantitative and qualitative scores and therefore was included in the candidates of promising countries. In the final stage of selecting promising export target countries using $\mathrm{BMO}$ method, the market attractiveness score was high but the strategic cooperation relationship with the competing country (Italy) and low evaluation of human network and marketing ability led to UAE being labeled as 'moderately recommended' country.

Indonesia, like UAE was grouped into $\mathrm{G} 2$ as a country that need replacement due to deterioration. The price was higher compared to competing weapon systems but the performance was far superior. Therefore, the cost-effectiveness was much superior. In the 1st screening, Indonesia was in the top group and Indonesia was included in the exportable countries. In the 2nd screening, Indonesia received above average points in both overall quantitative and qualitative scores and therefore was also, included in the candidates of promising countries. In the final stage of selecting promising export target countries using BMO method, both the market attractiveness and export competitiveness scores were high and this led to Indonesia being labeled as 'promising' country. 
Comparison of the actual successful/failed export cases and the applied results show near-identical results thus validating the viable possibility of the proposed methodology.

\section{CONCLUSION}

In this research, a new evaluation model for identifying target markets for weapon systems researched and developed in Korea. And the proposed methodology was validated by comparing the application results with two actual T-50 export cases where Indonesia (successful export), Philippines and USA were labeled as 'strongly recommended', UAE (failed attempt) and Saudi Arabia were labeled as 'moderately recommended' and Iraq was labeled as 'partially recommended' countries. The actual cases and the application results are sufficiently similar. Both countries passed the 2nd screening and were included in the candidates of promising countries. After evaluating market attractiveness and export competitiveness, Indonesia was labeled as 'strongly recommended' while UAE was labeled as 'moderately recommended' country. Comparing the application results with the actual cases, it can be seen that the proposed methodology can sufficiently identify target markets for weapons export.

To increase reliability and utilization of the proposed methodology, the further research in the following areas are considered.

First, systematic construction of global buying power DB to support weapons export decisions is required. Unlike civilian product export, much factors need to be considered for weapon systems export. Therefore, more factors that can be used to clearly define target country's buying power need to be identified. And much effort must be made to acquire related data/information.

Second, research on market price estimation of competing weapons system is also demanded. The unit price of a weapon system is very difficult to estimate because the price reflects the target weapon system's performance, the degree of systematic construction of main equipment and support equipment and the negotiation results of export target country. During this research, many reputable sources were consulted to shed credibility to the outcome. However, many sources have different views, evaluations and expectations. Therefore, acquisition of price information from various sources and respective credibility as well as technological price estimation must be made available to both obtain accurate competing weapon system price and estimation of competing/similar weapon system's prices.
Third, acquisition of expert pool for evaluation of technology performance, target market attractiveness export competitiveness is required. Weapon systems export requires the analysis of qualitative factors such as climatic environment of target countries, competition status comparison with competing countries and government support. However because of the characteristics of weapon systems, the number of technology experts of export experts is few. Therefore, pool of major technology/export experts from various institutes such as DAPA, DTaQ, ADD, KIDA must be built and maintained.

\section{ACKNOWLEDGEMENTS}

The research reported in this study was conducted during the sabbatical year of Kwangwoon University in 2015. This research was supported by the Ministry of Education of the Republic of Korea and the National ResearchFoundation of Korea (NRF-2017S1A5B8060156).

\section{REFERENCES}

Anonymous, 2007. Market research analysis and export strategy establishment for vitalizing defense export. Defense Acquisition Program Administration, Seoul, South Korea.

Anonymous, 2015. A study on promotion plan of military research and development considering export. Defense Acquisition Program Administration, Seoul, South Korea.

Anonymous, 2016a. TIV of Arms export 2008-2014 database. Stockholm International Peace Research Institute, Solna, Sweden.

Anonymous, 2016b. The sipri top 100 Arms-producing companies. Stockholm International Peace Research Institute, Solna, Sweden.

Aulakh, P.S., 1997. Global marketing: Foreign entry, local marketing and global management. J. Intl. Marketing, 5: 103-105.

Baumgartner, R.J., 2014. Managing corporate sustainability and CSR: A conceptual framework combining values, strategies and instruments contributing to sustainable development. Corporate Soc. Responsibility Environ. Manage., 21: 258-271.

Cavusgil, S.T., 1985. Guidelines for export market research. Bus. Horiz., 28: 27-33.

Cavusgil, S.T., T. Kiyak and S. Yeniyurt, 2004. Complementary approaches to preliminary foreign market opportunity assessment: Country clustering and country ranking. Ind. Marketing Manage., 33: 607-617. 
Choi, J.C., I.Y. Choi and J.K. Kim, 2009. Development of Korean green business/IT strategies using delphi technique. Korean Manage. Sci. Rev., 26: 91-112.

Dalkey, N., 1969. An experimental study of group opinion: The Delphi method. Futures, 1: 408-426.

Gorecka, D. and M. Szalucka, 2013. Country market selection in international expansion using multicriteria decision aiding methods. Multiple Criteria Decis. Making, 8: 32-55.

Han, B.Y. and J.H. Won, 2012. Research on R\&D requirement planning support strategies to foster arms exports: Focused on researching the evaluation model of marketability of weapon systems. J. Technol. Innovation, 20: 93-128.

Huszagh, S.M., 1986. Global marketing: An empirical investigation. Intl. Executive, 28: 7-9.

Index, G.P., 2016. Global peace ranking. Institute for Economics and Peace, New York, USA.

Jeong, S., J. Han and J. Kim, 2016. A systematic approach to identify promising new items for small to medium enterprises: A case study. Sustainability, 8: 1-14.

Jin, S.H., S.J. Jeong and K.S. Kim, 2017. A linkage model of supply chain operation and financial performance for economic sustainability of firm. Sustainability, 9: 1-23.

Koch, A.J., 2001. Selecting overseas markets and entry modes: Two decision processes or one? Marketing Intell. Plann., 19: 65-75.

Kumar, V., A. Stam and E.A. Joachimsthaler, 1994. An interactive multicriteria approach to identifying potential foreign markets. J. Intl. Marketing, 2: 29-52.
Lindberg, B.C., 1982. International comparison of growth in demand for a new durable consumer product. $\mathrm{J}$. Marketing Res., 19: 364-371.

Lloret, A., 2016. Modeling corporate sustainability strategy. J. Bus. Res., 69: 418-425.

Merrifield, D.B., 1978. How to select successful R\&D projects. Manage. Rev., 67: 25-39.

Saaty, T.L., 2003. Decision-making with the AHP: Why is the principal eigenvector necessary. Eur. J. Oper. Res., 145: 85-91.

Sakarya, S., M. Eckman and K.H. Hyllegard, 2007. Market selection for international expansion: Assessing opportunities in emerging markets. Intl. Marketing Rev., 24: 208-238.

Samli, A.C., 1977. An approach for estimating market potential in East Europe. J. Intl. Bus. Stud., 8: 49-54.

Sethi, S.P. and D. Curry, 1973. Variable and object clustering of cross-cultural data: Some implications for comparative research and policy formulation. Multinational Bus. Oper., 2: 19-49.

Sheth, J.N. and R.J. Lutz, 1971. A multivariate model of multinational business expansion. Master Thesis, University of Illinois at Urbana-Champaign, Champaign, Illinois, USA.

The International the International Institute of Strategic Studies, 2016. The Military Balance. Vol. 116, Routledge, London, England, UK., ISBN:9781857438352, Pages: 504.

Zolingen, S.J.V. and C.A. Klaassen, 2003. Selection processes in a Delphi study about key qualifications in senior secondary vocational education. Technol. Forecasting Soc. Change, 70: 317-340. 